\title{
Hospital discharge plan for patients with congestive heart failure
}

\author{
Maria Paula Andrietta ${ }^{1}$ \\ Rita Simone Lopes Moreira ${ }^{2}$ \\ Alba Lucia Bottura Leite de Barros ${ }^{3}$
}

This integrative review investigates how nurses plan the hospital discharge of patients with Congestive Heart Failure (CHF) since an inadequate discharge plan and patients' subsequent non-adherence to instruction provided upon discharge are indicated as potential factors for re-hospitalization. A total of 24 papers were found in a search carried out in the LILACS and MEDLINE databases between 2004 and 2008, which given the inclusion criteria, were reduced to 14 papers. The papers were analyzed and categorized into 'Health Education', and 'Nursing Care'. The synthesis of results indicates that the discharge plan devised by nurses is based on two categories. The actions of nurses to promote health education can enable patients with CHF to improve self-care.

Descriptors: Nursing; Patient Discharge; Heart Failure.

\footnotetext{
${ }^{1}$ RN, Student from specialization course in Cardiology Nursing, Instituto do Coração, Hospital das Clínicas, Faculdade de Medicina, Universidade de São Paulo, SP, Brazil. E-mail: mpandrietta@gmail.com.

2 RN, Doctoral student in Medicine, Universidade Federal de São Paulo, SP, Brazil. E-mail: rita.simone@unifesp.br.

${ }^{3}$ RN, Ph.D. in Physiopharmacology, Full Professor, Escola Paulista de Enfermagem, Universidade Federal de São Paulo, SP, Brazil. E-mail: barros.alba@unifesp.br.
}

Corresponding Author:

Alba Lucia Bottura Leite de Barros

Rua General Raposo, 70

Vila Clementino

CEP: 04044-070, São Paulo, SP, Brasil

E-mail: barros.alba@unifesp.br 


\section{Plano de alta hospitalar a pacientes com insuficiência cardíaca congestiva}

Trata-se de artigo de revisão integrativa que teve por objetivo identificar como as enfermeiras têm planejado a alta dos pacientes com insuficiência cardíaca congestiva, pois o inadequado plano de alta e o não seguimento das orientações dadas são apontados como possíveis fatores de re-hospitalização. Através da busca nas bases de dados LILACS e MEDLINE, abrangendo o período de 2004 a 2008, foram encontrados 24 artigos que, pelo critério de seleção da amostra, resultaram em 14. Os artigos foram analisados e categorizados em Educação em Saúde e Cuidado de Enfermagem. Com isso, foi possível sintetizar os resultados e identificar que o plano de alta realizado pelos enfermeiros está baseado nessas duas categorias, pois as condutas do enfermeiro para promover a educação em saúde podem proporcionar ao paciente com insuficiência cardíaca congestiva melhora no autocuidado.

Descritores: Enfermagem; Alta do Paciente; Insuficiência Cardíaca Congestiva.

\section{Plan del alta hospitalaria para pacientes con insuficiencia cardíaca congestiva}

Artículo de revisión integradora que tiene por objetivo identificar como las enfermeras han planificado el alta de los pacientes con Insuficiencia Cardíaca Congestiva, ya que el plan de alta inadecuado y el no seguimiento de las orientaciones dadas son apuntados como posibles factores de rehospitalización. A través de la búsqueda en las bases de datos LILACS y MEDLINE, abarcando el período de 2.004 a 2.008, fueron encontrados 24 artículos, que por el criterio de selección de la muestra resultaron en 14. Los artículos fueron analizados y categorizados en Educación en Salud y Cuidado de Enfermería. Con eso fue posible sintetizar los resultados e identificar que el plan de alta realizado por los enfermeros está basado en estas dos categorías, ya que a través de las conductas del enfermero para promover la educación en salud será posible proporcionar al paciente con Insuficiencia Cardíaca Congestiva una mejoría en el autocuidado.

Descriptores: Enfermería; Alta del Paciente; Insuficiencia Cardíaca.

\section{Introduction}

The nursing process is a systematized work method used by nurses for delivering care. It consists of five inter-related stages: investigation, diagnosis, planning, implementation and evaluation, which comprise a systematic and dynamic way to deliver nursing care. Planning refers to the determination of desired outcomes and the identification of interventions to achieve such results. Implementation refers to the establishment of a plan of action and observation of initial responses ${ }^{(1)}$.

A discharge plan should be based on investigation performed during data collection and on data collected during hospitalization including the limitations of the patient, the family, the caregiver or environment, in addition to existing resources. These data compose the implementation and coordination of the care plan. This is an essential process of exchanging information with the patient, caregivers and those responsible for care(2-3).

Inadequately planning discharge from the hospital and patients' non-adherence to instructions are indicated as factors that lead to the re-hospitalization of patients with heart failure, which shows the importance of a discharge plan to improve quality of life for patients ${ }^{(4)}$.

Heart Failure (HF) is a clinical condition in which the heart is unable to pump the necessary volume of blood to meet the demands of tissue metabolism. HF can be acute, that is, it may have a rapid onset or clinical change of signs and symptoms, resulting in an urgent need for therapy. Acute HF or Congestive Hearth 
Failure ( $\mathrm{CHF}$ ) may be a new condition or a consequence of a worsened pre-existing HF (Decompensated Chronic Heart Failure) $)^{(5)}$.

Acute decompensated $\mathrm{HF}$, which results in hospitalization, causes certain specific problems. First, acute HF marks an essential change in the natural history of the disease. Mortality rates in the year following hospitalization caused by HF are higher than among those who were not hospitalized. Hospitalization given HF remains as one of the most important risk factors for mortality. Second, hospitalization given acute HF generates by itself more hospitalizations; the rehospitalization rate is $50 \%$ within the 12 months after hospital discharge. Third, hospitalizations given HF account for more than 30 billion dollars used yearly in care delivered to these patients. Hence, any reduction in hospitalization rates can result in substantial economic gains and clinical improvement for patients ${ }^{(6)}$.

The HF diagnosis is based on anamnesis and a detailed physical assessment in which signs and symptoms due to low cardiac output and pulmonary and systemic congestive phenomena are verified(5). Because $\mathrm{CHF}$ is a highly complex syndrome, it requires patients to be prepared for hospital discharge, which is an important responsibility of nurses. For such decisionmaking, professionals should use scientific evidence to support critical rationale ${ }^{(7)}$.

\section{Objective}

\section{To identify in the literature how nurses plan the discharge of patients with CHF.}

\section{Method}

The integrative review method was used to synthesize published studies and draw conclusions concerning the topic of interest ${ }^{(8)}$, such as the incorporation of scientific evidence in knowledge in the topic, aiming to improve the hospital discharge of patients with CHF.

An integrative review presents a set of studies already published that allows one to draw conclusions concerning the topic. A well-conducted integrative review requires the same standards of rigor, clarity and the possibility of replicating results that are used in primary studies ${ }^{(9)}$.

This type of review is important because it supports the implementation of changes that promote the quality of nursing conduct through research models ${ }^{(10)}$, in addition to offering nurses rapid access to relevant results of studies addressing decision-making, promoting critical knowledge ${ }^{(11)}$.

The integrative review is one of the review methods recommended in Evidence-Based Practice (EBP) for nursing because it enables the search for evidence available on the studied theme, along with critical evaluation and synthesis of that evidence(12). EBP incorporates evidence originating from studies, professional clinical competence, and preferences of clients for decision-making concerning health care ${ }^{(13)}$.

According to the classification of evidence, there are grades ( $, B, C$, and $D)$ of recommendation that reflect the scientific credibility of studies and levels of evidence $(1,2,3,4$ and 5$)$ that show the quality of evidence ${ }^{(14)}$ There were five papers classified with a grade of $A$, five with a grade of $B$, three with a $C$, and one with a $D$. Five were graded at level 1 for evidence, three with level 2 , two were level 3, three were level 4 and one with level 5 for evidence.

The integrative review phases suggested by Ganong were used in this study: selecting the questions for review; establishing criteria for sample selection, presenting the characteristics of primary research, analyzing data, interpreting results and presenting the review.

The following guiding question was asked: "How do nurses plan the hospital discharge of patients with CHF?"

The following subject descriptors were used: "nursing", "discharge planning" and "heart failure" based on MeSH (MEDLINE) and DeCS (BIREME) aiming to use a unique language in the search for scientific papers.

The search for papers was carried out between March and May 2009. Review covered from 2004 to 2008, including papers written in Portuguese and English, addressing discharge planning, heart failure and nurses. The papers were included after their titles and abstracts were analyzed. The LILACS and MEDLINE databases were consulted.

A total of 24 papers were found: five in the LILACS database, three of which were excluded because they addressed nursing consultation and physiopathology contextualization rather than hospital discharge; 19 were found in the MEDLINE database, seven of which were excluded because three addressed $\mathrm{CHF}$ treatment with ventricular assist devices and surgery techniques, one discussed sleep disorders in caregivers of patients with $\mathrm{CHF}$, one superficially addressed discharge planning, one discussed the period after hospital discharge and one did not discuss discharge planning. Hence, a total of 14 papers composed the sample.

The papers were analyzed according to: 
identification (authors, authors' background, year, language, database, and periodical) and characteristics of the paper (title, objective, study's design, result and conclusion).

\section{Results}

Data analysis was descriptive and the synthesis of data of each study is presented. Of the total of 14 $(100 \%)$ selected papers, three $(21.42 \%)$ were written by a single author; two (14.29\%) by two authors; and nine $(64.29 \%)$ papers were written by three or more authors. Among the five years selected (2004-2008): one (7.14\%) paper was published in 2004 ; two (14.29\%) in 2005; four (28.57\%) in 2006; two (14.29\%) in 2007 and five (35.71\%) in 2008 .

As for the authorship, ten $(71.43 \%)$ papers were written by nurses, three $(21.43 \%)$ by nurses and physicians and one (7.14\%) was written by physicians. In relation to the periodicals, two (14.29\%) papers were published in Brazilian periodicals and 12 (85.71\%) in international periodicals: 12 (85.71\%) were in English and two (14.29\%) in Portuguese.

The papers were organized into the categories: 'Health Education' and 'Nursing Care'. Figures 1 and 2 present the synthesis of papers included in the study and the classification of scientific evidence.

\begin{tabular}{|c|c|c|c|}
\hline Author & Title & Design/Evidence & Conclusions \\
\hline $\begin{array}{l}\text { Costa CMV, Santos } \\
\text { ZMSA, Saraiva KRO }\end{array}$ & $\begin{array}{l}\text { Client with heart failure: self- } \\
\text { care demands }\end{array}$ & $\begin{array}{l}\text { Descriptive study } \\
5 D\end{array}$ & $\begin{array}{l}\text { CHF requires nurses to be health educators and implement } \\
\text { preventive and/or therapeutic actions to help patients' self- } \\
\text { care in order to improve their deficit of knowledge concerning } \\
\text { the disease, acceptance of the disease and treatment } \\
\text { adherence. }\end{array}$ \\
\hline $\begin{array}{l}\text { Aliti GB, Brun AO, } \\
\text { Domingues FB, } \\
\text { Rabelo ER, Rushel } \\
\text { KB }\end{array}$ & $\begin{array}{l}\text { What to teach to patients with } \\
\text { heart failure and why: the } \\
\text { role of nurses in heart failure } \\
\text { clinics }\end{array}$ & $\begin{array}{l}\text { Systematic Review of } \\
\text { Randomized Controlled Trial } \\
1 \mathrm{~A}\end{array}$ & $\begin{array}{l}\text { Health education is required for patients to understand CHF } \\
\text { and develop self-care skills to improve treatment adherence } \\
\text { and avoid decompensation. The nurses' discharge planning } \\
\text { should include daily visits to monitor the patient's progress } \\
\text { and reinforce adherence, support the patient and family, and } \\
\text { emphasize the importance of recognizing worsening signs } \\
\text { and symptoms. }\end{array}$ \\
\hline Albert, NM & $\begin{array}{l}\text { Improving medication } \\
\text { adherence in chronic } \\
\text { cardiovascular disease }\end{array}$ & $\begin{array}{l}\text { Case report } \\
4 \mathrm{C}\end{array}$ & $\begin{array}{l}\text { Nurses are responsible for educating patients before } \\
\text { discharge concerning how to take the medication. This } \\
\text { study provides evidence that education provided by nurses } \\
\text { improves treatment adherence, self-care and reduces } \\
\text { costs. It also shows the importance of monitoring patients } \\
\text { after discharge so they keep taking their medication, which } \\
\text { can be achieved through clinical visits, phone calls, and by } \\
\text { simplifying their therapeutic regime. }\end{array}$ \\
\hline Paul S & $\begin{array}{l}\text { Hospital discharge education } \\
\text { for patients with heart failure: } \\
\text { what really works and what is } \\
\text { the evidence? }\end{array}$ & $\begin{array}{l}\text { Systematic Review of } \\
\text { Randomized Controlled Trial } \\
\text { 1A }\end{array}$ & $\begin{array}{l}\text { Educating patients for hospital discharge promotes self- } \\
\text { care, reduces the chances of re-hospitalization and helps } \\
\text { patients to identify early worsening signs and symptoms. } \\
\text { A recommendation for discharge is to provide patients with } \\
\text { educational material containing information concerning } \\
\text { medication, diet, exercise and weight control. Monitoring } \\
\text { patients after discharge is important to the continued } \\
\text { provision of health education through the use of books, } \\
\text { CDs, videos, computer and newspapers, since the volume } \\
\text { of information provided at the time of hospital discharge is } \\
\text { large. }\end{array}$ \\
\hline $\begin{array}{l}\text { Collins S, Dierks } \\
\text { D, Emerman C, } \\
\text { Peacock WF }\end{array}$ & $\begin{array}{l}\text { Heart failure observation } \\
\text { units: optimizing care }\end{array}$ & $\begin{array}{l}\text { Systematic Review of case- } \\
\text { control study } \\
\text { 3A }\end{array}$ & $\begin{array}{l}\text { The discharge planned by nurses should contain } \\
\text { recommendations concerning diet, medication schedule, } \\
\text { and weight control. Care planning should include outpatient } \\
\text { follow-up. Patients should have knowledge concerning the } \\
\text { disease, the relation between pharmacological therapy } \\
\text { and disease, between healthy habits and disease, and } \\
\text { decompensation signs and symptoms. Such procedures } \\
\text { reduce costs and readmission. }\end{array}$ \\
\hline $\begin{array}{l}\text { Carroll KC, Gardetto } \\
\text { NJ }\end{array}$ & $\begin{array}{l}\text { Management strategies } \\
\text { to meet the core heart } \\
\text { failure measures for acute } \\
\text { decompensated heart failure }\end{array}$ & $\begin{array}{l}\text { Case study } \\
4 \mathrm{C}\end{array}$ & $\begin{array}{l}\text { Nurses should prepare a written discharge plan containing } \\
\text { activities, fluids and sodium restrictions, diet, daily weight } \\
\text { control, medications, and how to proceed in case symptoms } \\
\text { worsen to avoid future hospitalizations. }\end{array}$ \\
\hline $\begin{array}{l}\text { Koelling TM, Johnson } \\
\text { ML, Cody RJ, } \\
\text { Aaronson KD }\end{array}$ & $\begin{array}{l}\text { Discharge education improves } \\
\text { outcomes in patients with } \\
\text { chronic heart failure }\end{array}$ & $\begin{array}{l}\text { Randomized Controlled Trial } \\
\text { 1B }\end{array}$ & $\begin{array}{l}\text { Guidance and education provided to patients is used in the } \\
\text { discharge plan as measures to improve patients' self-care. } \\
\text { Information for the discharge plan was disseminated by } \\
\text { a nurse and contained a list of medication, dose, how to } \\
\text { take medication and side effects, diet, sodium and water } \\
\text { restrictions, daily weight control, information concerning } \\
\text { pneumococcal/influenza vaccines, exercise, follow-up visits, } \\
\text { advice to quit smoking, avoid alcohol and non-steroidal } \\
\text { anti-inflammatory medication and how to proceed if the } \\
\text { symptoms worse. Such measures reduced hospitalizations } \\
\text { and costs. }\end{array}$ \\
\hline
\end{tabular}




\begin{tabular}{|c|c|c|c|}
\hline Author & Title & Design/Evidence & Conclusions \\
\hline $\begin{array}{l}\text { Bayliss D, Craighead } \\
\text { J, Luzinski CH, } \\
\text { Schmidt M, Seidman } \\
\text { J, Stockbridge E }\end{array}$ & $\begin{array}{l}\text { The community case } \\
\text { management program: for } 12 \\
\text { years, caring at its best }\end{array}$ & $\begin{array}{l}\text { Case report } \\
4 \mathrm{C}\end{array}$ & $\begin{array}{l}\text { Factors that collaborate in patient discharge are: planning } \\
\text { individual care, home visits, phone calls, and good } \\
\text { relationships established among patient, family and nurse } \\
\text { (empathy and good humor). }\end{array}$ \\
\hline $\begin{array}{l}\text { Lesperance ME, Bell } \\
\text { SE, Ervin NE }\end{array}$ & $\begin{array}{l}\text { Heart failure and weight gain } \\
\text { monitoring }\end{array}$ & $\begin{array}{l}\text { Retrospective descriptive } \\
\text { study } \\
\text { 3B }\end{array}$ & $\begin{array}{l}\text { A hospital discharge planned by nurses should be } \\
\text { individualized. Lack of communication among nurses } \\
\text { and patient and caregiver hinders care plan. Nursing } \\
\text { documentation should contain instruction concerning } \\
\text { discharge and take into account the patient's cognitive skills. } \\
\text { Factors that may contribute to failures in a discharge plan } \\
\text { include: few nurses per shift and a high number of patients } \\
\text { to care for. Nurses should also evaluate the financial, safety } \\
\text { and psychosocial needs of patients that may hinder the } \\
\text { patient's and family's ability to follow the discharge plan. } \\
\text { Nurses who monitor through phone calls contribute to early } \\
\text { patient-identification of signs and symptoms indicating that } \\
\text { CHF is worsening. This measure reduces re-hospitalization } \\
\text { rates. }\end{array}$ \\
\hline McCoy ML & $\begin{array}{l}\text { Care of congestive heart } \\
\text { failure patient: the care, cure } \\
\text { and core model }\end{array}$ & $\begin{array}{l}\text { Cohort study } \\
\text { 2B }\end{array}$ & $\begin{array}{l}\text { The relationship between nurse and patient is important } \\
\text { to solving problems and promoting care and education to } \\
\text { encourage a patient's effective self-care. Open and reliable } \\
\text { communication facilitates care, promotes education, and } \\
\text { organizes a discharge plan. In addition to the physical } \\
\text { aspect, nurses can also evaluate the emotional and social } \\
\text { needs of patients to acquire a more holistic view of patients. }\end{array}$ \\
\hline $\begin{array}{l}\text { McCaffrey R, } \\
\text { Delgado-Passler P }\end{array}$ & $\begin{array}{l}\text { The influences of post } \\
\text { discharge management by } \\
\text { nurse practitioners on hospital } \\
\text { readmission for heart failure }\end{array}$ & $\begin{array}{l}\text { Systematic Review of } \\
\text { Randomized Controlled Trial } \\
1 \mathrm{~A}\end{array}$ & $\begin{array}{l}\text { Nurses should take care so that the discharge plan considers } \\
\text { the needs and resources of patients for keeping up with } \\
\text { follow-up after discharge through phone calls, home visits, } \\
\text { and visits to the specialty outpatient clinic. }\end{array}$ \\
\hline $\begin{array}{l}\text { Griffith S, Kwok T, } \\
\text { Lee DT, Lee J, Woo J }\end{array}$ & $\begin{array}{l}\text { A randomized controlled } \\
\text { trial of a community nurse- } \\
\text { supported hospital discharge } \\
\text { program in older patients with } \\
\text { chronic heart failure }\end{array}$ & $\begin{array}{l}\text { Randomized Controlled Trial } \\
\text { 1B }\end{array}$ & $\begin{array}{l}\text { An appropriate discharge plan for CHF patients and } \\
\text { evaluation of the patient's needs in order to maintain } \\
\text { follow-up after discharge has been efficient in preventing } \\
\text { re-hospitalizations. }\end{array}$ \\
\hline $\begin{array}{l}\text { Anderson MA, Brown } \\
\text { SM, Brown-Benn C, } \\
\text { Bryant PJ, Burr CM, } \\
\text { Dusio ME, Levsen J }\end{array}$ & $\begin{array}{l}\text { Evidence-based factors in } \\
\text { readmission of patients with } \\
\text { heart failure }\end{array}$ & $\begin{array}{l}\text { Systematic Review of Cohort } \\
\text { Studies } \\
2 \mathrm{~A}\end{array}$ & $\begin{array}{l}\text { Nurses should start the discharge plan at the patient's } \\
\text { admission in order to identify demographic, psychosocial, } \\
\text { and physiological domains to establish re-hospitalization } \\
\text { variables at the time of admission and discharge, which } \\
\text { permits the development of an individualized plan. }\end{array}$ \\
\hline $\begin{array}{l}\text { Cockburn J, } \\
\text { Davidson PM, } \\
\text { Newton PJ }\end{array}$ & $\begin{array}{l}\text { Unmet needs following } \\
\text { hospitalization with heart } \\
\text { failure }\end{array}$ & $\begin{array}{l}\text { Cohort study } \\
\text { 2B }\end{array}$ & $\begin{array}{l}\text { Individualized discharge planning takes into account quality } \\
\text { of life, sleep pattern, depression and social isolation. }\end{array}$ \\
\hline
\end{tabular}

Figure 2 - Papers that involved the category 'Nursing Care'

\section{Health Education}

Improving knowledge for self-care is essential to successfully reducing morbidity and mortality and health costs related to $\mathrm{HF}^{(15)}$. Health education is required to promote self-care in order to daily monitor weight, restrict the intake of fluids and sodium, practice exercises programmed individually, maintain the regular use of medication, monitor signs and symptoms indicating worsening of the disease and keep contact with the team $^{(16-17)}$.

The most common factors contributing to undermining self-care are related to a lack of knowledge concerning the disease and treatment; non-adherence to treatment and the disease's clinical manifestation; non-acceptance of the disease; lack of family support; slight (temporary) improvement of symptoms; complex drug therapy; side effects of medication; and prolonged treatment without a prospect for a cure(16-18).
Educational nursing interventions in the Brazilian context implemented during hospitalization improve knowledge concerning $\mathrm{HF}$, self-care and the quality of life of patients and their family members ${ }^{(15)}$.

Health education depends on a multi-disciplinary team that provides knowledge and sensitizes patients concerning the disease so that they adhere to their treatment, restrict the intake of sodium and fluids, and recognize signs and symptoms that indicate the disease is progressing(19). Additionally, educating patients concerning their own disease, the relation between the pharmacological therapy and the disease, and also between healthy behavior and the disease, can influence re-hospitalization rates $^{(20)}$.

Books, educational booklets, videos, CDs, web pages, and computer programs are used in educational health strategies to increase patients' understanding in addition to offering opportunities to implement follow-up by phone 
or support group, because the volume of information provided at the time of discharge is very large ${ }^{(19)}$.

Another possibility for teaching health education that may be used by nurses is a frequent educational scheme. Nurses draw a table with the patient's name and the medication schedule highlighting the name of the medication, its indication, dose, time and side effects $^{(17)}$.

The Heart Failure Society of America recognizes the importance of health education and recommends that patients receive educational material as part of the instructions provided at the time of discharge. The Joint Commission also recommends that HF patients should receive written instruction at the time of discharge based on directives and guidelines ${ }^{(19,21)}$.

Written discharge instructions or educational material provided to patients should contain: suggestions for mild activities, diet, a list of medication with respective doses ${ }^{(22)}$, daily weight control, and a guide to worsening symptoms. This measure reinforces the ability of patients to recognize HF symptoms ${ }^{(23)}$.

An appropriate discharge plan that focuses on health education and disease management promotes improved results and reduction of costs because treatment adherence contributes to reducing re-hospitalization rates $^{(18,20,24)}$.

There are barriers in the teaching of health education such as: complex and confusing therapeutic regimes; the cognitive impairment of some patients, which hinders compliance with instructions; or even a lack of motivation to follow instruction provided in the discharge plan ${ }^{(19)}$.

\section{Nursing Care}

Nursing care concerning instruction provided to patients that validated this practice promotes greater treatment adherence and consequently improves clinical outcomes. Trust in the nurse-patient relationship encourages treatment and improves adherence to it ${ }^{(18,25)}$. Additionally, communication between both parties should be open and reliable to facilitate care, education, and organization of the discharge plan (24).

Nursing practice to reinforce knowledge concerning the disease and follow-up of patient treatment adherence and behavioral changes can be achieved through home visits and phone calls. These measures help patients to continue treatment because they promote the memorization of instructions and clarification of doubts that may arise during the treatment ${ }^{(18-19,25-26)}$, in addition to the identification of signs and symptoms indicating their HF is worsening and encouraging patients to seek early intervention before hospitalization is required ${ }^{(23)}$. Home visits by nurses from the public health network after hospital discharge has been effective in preventing the re-hospitalization of HF patients(27).

Through an integrative review aimed to analyze evidence, variables related to hospital re-admission were classified into the following domains: demographic, physiological, and psychosocial. These domains should be identified through an individual plan from hospitalization up to discharge to avoid re-admissions ${ }^{(28-29)}$

Another proposed model focuses on physical, social and emotional needs. This model is divided into three phases. The first, which is called "Care," includes daily activities performed by the nursing staff and, as a result, reduces anxiety and increases the patient's comfort. It is in this phase that the education of patients and discharge-planning is initiated. The second phase, "Cure" is responsible for treatment, and the third phase "Core" refers to the emotional and social structure of patients. This model improves knowledge and the ability for patients to self-manage their disease, preventing the condition from being aggravated with consequent re-hospitalization(24). Improving the discharge plan outcomes through nursing interventions, education and self-care reduce costs from hospitalization and emergency care ${ }^{(18,25)}$.

The instruction provided at discharge and the ability of patients to understand it should be recorded in nursing documentation.

Factors that impede achieving success in the discharge plan include: too few nurses per shift and a high number of patients. Long shifts also enable nurses to take more days off per week and, consequently, nurses see the patients less frequently during hospitalization ${ }^{(23)}$.

The papers' synthesis shows the importance of knowledge concerning the levels of evidence classification system because it supports nurses during the critical evaluation of results originating in research and, consequently, during decision-making concerning evidence-based clinical practice ${ }^{(30)}$.

\section{Discussion}

The results from the synthesis of primary studies included in this review were discussed based on the literature.

$\mathrm{HF}$ is a pathology with high mortality and morbidity rates, a high number of hospitalizations per year and imposes a high cost on the health system, which shows 
the importance of HF for health systems at a world level(15-29).

HF presents a high level of re-hospitalizations due to a lack of knowledge concerning the disease, non-acceptance of the disease, lack of adherence to treatment, complex and costly treatment, lack of family support, (temporary) slight improvement of symptoms, medications' side effects, and prolonged treatment without possibility of cure ${ }^{(16-18)}$.

Education is required for patients to understand the health-disease process, while knowledge acquired by patients promotes self-care, reducing hospitalization rates $^{(15,18,20,26)}$. HF patients should monitor their weight daily, restrict the intake of sodium and fluids, exercise, use their medication, monitor signs and symptoms indicating the worsening of their condition and maintain follow-up ${ }^{(17,23,27)}$.

Nurses promote health education through providing instruction to facilitate the understanding of patients and collaborating in the discharge plan. They also promote health education by visiting patients at home to continue education and clarify doubts and through phone follow-up in case any sign or symptom indicates the disease is worsening(17-19,22,25-26). The nurse-patient relationship increases trust in the professional and encourages adherence to the discharge plan on the part of patients ${ }^{(18,24-25)}$.

Another nursing action that helps with the care plan is the identification of physical, psychological and spiritual needs, because in addition to a holistic view of the patients, it enables more individualized care ${ }^{(23,28,31)}$.

Nursing documentation should contain information as to whether patient's discharge was planned or not and also whether instruction was understood. There is a possibility that such information goes undocumented due to too few nurses per shift and a high number of patients, which reduces the time available for documentation and discharge planning ${ }^{(23)}$.

The synthesis of the primary studies indicates that there is generally no previously prepared discharge plan, though there is evidence of actions that can contribute to the development of a good discharge plan, promote adherence to it on the part of patients, reduce rehospitalization rates, and lower costs.

\section{Conclusion}

Data presented here show what aspects compose the hospital discharge plan of CHF patients, how nurses plan it, and the plan's outcomes, such as reduced re- hospitalization rates and costs for the health system.

This study contributed to deepening knowledge of the investigated theme and led to the conclusion that the discharge plan is extremely important for HF patients and that nurses have an essential role in planning it. The discharge plan should be integral and individualized even after hospital discharge with nursing actions that promote health education and self-care, including aspects such as weight control, salt and fluids restrictions, guidance regarding medication, exercise, diet and coaching on the symptoms that indicate the disease is worsening.

There are some gaps in this study related to the patients' lack of knowledge concerning the disease and treatment; whether nurses have time and are prepared to plan individualized hospital discharges and whether these are sufficient to teach patients; whether patients and family members can validate the discharge plan since they receive a large amount of information at the time of hospital discharge; the availability of written educational material and instruction concerning the discharge plan; and whether patients adhere to treatment to ensure efficacy of hospital discharge.

In order to strengthen this study's results, further research is required addressing the development and implementation of discharge plans and also the impact of such plans on CHF patients, validation of patients' knowledge, family support of the discharge plan, and the development of educational material to educate patients. Additionally there are other aspects that can be scientifically addressed and result in evidence to be incorporated into nursing practice directed to $\mathrm{CHF}$ patients.

\section{References}

1. Alfaro-Lefevre R. Aplicação do Processo de Enfermagem Promoção do Cuidado Colaborativo. $5^{\mathrm{a}}$ ed. Porto Alegre: Artmed; 2005.

2. Taylor C. Fundamentos de Enfermagem: a arte e a ciência do cuidado de enfermagem. $5^{a}$ ed. Porto Alegre: Artmed; 2007.

3. Assis CC, Barros ALBL, Ganzarolli MZ. Evaluation Of Expected Outcomes Of Nursing Interventions To Address The Nursing Diagnosis of Fatigue Among Patients With Congestive Heart Failure. Acta Paul Enferm. 2007;20(3):357-61.

4. Bacal F, Flávio PGC. Insuficiência cardíaca congestiva. In: Quilici AP, editor. Enfermagem em Cardiologia. São Paulo: Atheneu; 2009. p. 325-38. 
5. Almeida DR. Insuficiência Cardíaca. Cardiologia. In: Prado FC, Ramos J, Valle JR, organizadores. Atualizações Terapêuticas. 22.ed. São Paulo: Artes Médicas; 2005. p. 150-2.

6. Montera MW, Almeida RA, Tinoco EM, Rocha RM, Moura LZ, Réa-Neto $A$, et al. Sociedade Brasileira de Cardiologia. II Diretriz Brasileira de Insuficiência Cardíaca Aguda. Arq Bras Cardiol. 2009;93(3 supl 3):1-65.

7. Ciliska D, Cullum N, Haynes RB, Marks S. Enfermagem Baseada em Evidências: Uma Introdução. Porto Alegre: Artmed; 2010.

8. Silveira CS, Zago MMF. Brazilian research in oncology nursing: an integrative review. Rev. Latino-Am. Enfermagem. 2006;14(4):614-9.

9. Beya SC, Nicholl LH. Writing an integrative review. AORN J. 1998;67(4):877-80.

10. Ganong LH. Integrative reviews of nursing research. Res Nurs Health. 1987;10(1):1-11.

11. Mendes KDS, Silveira RCCP, Galvão CM. Integrative Literature Review: a research method to incorporate evidence in health care and nursing. Texto Contexto Enferm. 2008;17(4):758-64.

12. Whittemore $R$, Knafl $K$. The integrative review: updated methodology. J Adv Nurs. 2005;52(5):546-53. 13. Silveira RCCP, Galvão CM. Nursing Care and Hickman's catheter: the search for evidence. Acta Paul Enferm. 2005;18(3):276-84.

14.Oxford Centre for Evidence-based Medicine. Levels of evidence and grades of recommendations; 2001. [acesso 25 fev 2009]. Disponível em: http://cebm.jr2. ox.ac.uk/docs/levels.html

15. Aliti GB, Assis MCS, Braum $S$, Domingues FB, Linhares JC, Rabelo ER, et al. Evidence-based nursing in cardiology. Rev HCPA. 2007;27(2):43-8.

16. Costa CMV, Santos ZMSA, Saraiva KRO. Client with heart failure: self-care demands. Esc Anna Nery. ago 2004;8(2):243-50.

17. Aliti GB, Brun AO, Domingues FB, Rabelo ER, Ruschel $K B$. What to teach to patients with heart failure and why: the role of nurses in heart failure clinics. Rev. Latino-Am. Enfermagem. 2007;15(1):165-70.

18. Albert NM. Improving Medication Adherence in Chronic Cardiovascular Disease. Crit Care Nurse. 2008 Oct;28(5):54-65.

19. Paul S. Hospital Discharge Education for Patients with Heart Failure: What Really Works and What Is the Evidence? Crit Care Nurse. 2008;28(2):66-82.

20. Collins S, Diercks D, Emermarm C, Peacock WF, Young J. Heart Faliure observations units: optimizing care. Ann Emerg Med. 2006 Jan;47(1):22-33.
21. Carroll KC, Gardetto NJ. Management Strategies to Meet the core heart failure measures for acute decompensated heart failure. Crit Care Nurs Q. 2007 Oct-Dec;30(4):307-20.

22. Aaronson KD, Cody RJ, Johnson ML, Koelling TM. Discharge education improves clinical outcomes in patients with chronic heart failure. Circulation. 2005;111(2):179-85.

23. Bell SE, Ervin NE, Lesperance ME. Heart Failure and weight gain monitoring. Lippincotts Case Manag. 2005 Nov-Dec;10(6):287-93.

24. MCcoy ML. Care of the Congestive Heart Failure Patient: The Care, Cure and Core Model. J Pract Nurse. 2006 Spring;56(1):5-6,30.

25. Craighead J, Luzinski CH, Schimidt M. The Community Case Management Program: for 12 years, Caring at Its Best. Geriatr Nurs. 2008;29(3):207-15.

26. Delgado-Passler $P, M C C a f f r e y ~ R$. The influences of postdischarge management by nurse practitioners on hospital admission for heart failure. J Am Acad Nurse Pract. 2006 Apr; 18(4):154-60.

27. Griffith S, Kwok T, Lee DT, Lee J, Woo J. A randomized controlled trial of a community nurse-supported hospital discharge programme in older patients with chronic heart failure. J Clin Nurs. 2008;17(1):109-17.

28. Anderson MA, Brown SM, Brown-Benn C, Bryant PJ, Dusio ME, Levsen J. Evidenced-based factors in readmission of patients with heart failure. J Nurs Care Qual. 2006 Apr-Jun;21(2):160-7.

29. Cockburn J, Davison, PM, Newton PJ. Unmet Needs Following Hospitalization with Heart Failure. J Cardiovasc Nurs. 2008;23(6):541-6.

30. Galvão CM. Editorial Níveis de Evidencia. Acta Paul Enferm. 2006;19(2):5.

31. Soares DA, Toledo JAS, Santos LF, Lima RMB, Galdeano LE. Quality of life of heart failure patients. Acta Paul Enferm. 2008;21(2):243-8. 